\title{
The effects of $\mathrm{CaCl}_{2}$ and $\mathrm{CaBr}_{2}$ on the reproduction of Daphnia magna Straus
}

\author{
Neda Mažuran ${ }^{1}$, Vladimir Hršak ${ }^{2}$, and Goran Kovačević ${ }^{3}$ \\ Salopekova 2b $b^{1}$, Division of Botany ${ }^{2}$, Division of Zoology ${ }^{3}$, Department of Biology, Faculty of Science, \\ University of Zagreb, Zagreb, Croatia
}

[Received in March 2014; CrossChecked in March 2014; Accepted in May 2015]

\begin{abstract}
Concentrated $\mathrm{CaCl}_{2}$ and $\mathrm{CaBr}_{2}$ salt solutions of densities up to $2.3 \mathrm{~kg} \mathrm{~L}^{-1}$ are regularly used to control hydrostatic pressure in oil wells during special operations in the exploration and production of natural gas and crude oil. Various concentrations of high density salts are frequently left in mud pits near the drilling site as waste, polluting fresh and ground waters by spillage and drainage. The toxic effects of these salts have already been observed. This study investigated the effects of $\mathrm{CaCl}_{2}$ and $\mathrm{CaBr}_{2}$ on water flea Daphnia magna Straus in a 21-day reproduction test. The three tested concentrations of $\mathrm{CaCl}_{2}^{2}\left(240,481\right.$, and $\left.1925 \mathrm{mg} \mathrm{L}^{-1}\right)$ caused a significant dose-response decrease of reproduction $(p<0.001)$. With $\mathrm{CaBr}_{2}$ (533 and $1066 \mathrm{mg} \mathrm{L}^{-1}$ ), only aborted eggs were produced, demonstrating the embryotoxicity of the substance. The results suggest that high concentrations of the tested chemicals are harmful to Daphnia's reproduction and could reduce its abundance.
\end{abstract}

KEY WORDS: acute immobilisation test; bromide embryotoxicity; chronic reproduction test; high density salts

Concentrated solutions of calcium chloride $\left(\mathrm{CaCl}_{2}\right)$ and calcium bromide $\left(\mathrm{CaBr}_{2}\right)$, densities from 1.39 to $2.30 \mathrm{~kg} \mathrm{~L}^{-1}$, and their mixtures commonly known as high density salts or clear brines, are extensively used as completion or workover fluids in oil and natural gas exploration and production industry. Their main function is to provide the required density that controls subsurface pressure in the formations with abnormally high pressure, as well as to minimize formation damage, maintain borehole stability, transport moveable solids, and suspend solids, all of which maximise the recovery of hydrocarbons from the production reservoir (1-3). After operations, high density brines are often left in the mud pits near the well site as waste and may pollute fresh and groundwater by spilling over and draining through the ground.

Several studies investigating the toxic effects of concentrated solutions of $\mathrm{CaCl}_{2}$ and $\mathrm{CaBr}_{2}$ have been performed using plant test systems and an animal test organism, the freshwater snail Planorbarius corneus (Linnaeus, 1758) (4-8). Studies on plants (4-7) showed a significant inhibition of duckweed (Lemna minor) growth at higher concentrations of $\mathrm{CaCl}_{2}(5550,8325$, and $\left.9624 \mathrm{mg} \mathrm{L}^{-1}\right)$ and $\mathrm{CaBr}_{2}\left(14931\right.$ and $\left.21320 \mathrm{mg} \mathrm{L}^{-1}\right)$. Photosynthetic pigments chlorophyll $a$ and $b$ increased and the stress indicator anthocyanin were also increased in greater duckweed (Spirodella polyrrhiza) (4-7). Growth inhibition was observed in the green algae Chlorella kessleri

Correspondence to: Vladimir Hršak, Department of Botany, Faculty of Science University of Zagreb, Marulićev trg 20, E-mail: vladimir.hrsak.@biol.pmf.hr at $21320 \mathrm{mg} \mathrm{L}^{-1} \mathrm{CaBr}_{2}$ (5). The study on $P$. corneus showed a significant dose response decrease of survival and fecundity (egg-mass number) in chronic toxicity test at concentrations ranging from 1203 to $4813 \mathrm{mg} \mathrm{L}^{-1} \mathrm{CaCl}_{2}$, 1066 to $5329 \mathrm{mg} \mathrm{L}^{-1} \mathrm{CaBr}_{2}$, and 774 to $5801 \mathrm{mg} \mathrm{L}^{-1}$ of their mixture 1:1 (8).

To further explore the toxic effects of $\mathrm{CaCl}_{2}$ and $\mathrm{CaBr}_{2}$, observed in our previous study on $P$. corneus (8), we selected Daphnia magna Straus as a model system to perform a semistatic 21-day reproduction test. This species frequently occupies habitats in north-western Croatia, where gas and oil exploration and production are performed. Furthermore, water fleas as primary grazers and primary forage for invertebrates and vertebrates represent ecologically important constituents of food webs and are also an established model commonly used in toxicology $(9,10)$.

\section{MATERIALS AND METHODS}

\section{Daphnia laboratory culture}

Daphnids originating from a local wild population and an unpolluted area were reared in the laboratory culture in $1000 \mathrm{~mL}$ glass vessels at a density of 50 individuals per L in dechlorinated tap water passed through activated charcoal. They were fed daily with a concentrated suspension of fresh cultured green algae Chlorella vulgaris and Scenedesmus obliquus alternately with an addition of suspended dry baking yeast once a week and kept at 
$20 \pm 2{ }^{\circ} \mathrm{C}$ at $12 / 12$ photoperiod (550 lux). Once a week, daphnids were transferred to fresh water and neonates were regularly removed.

\section{Acute and chronic semi-static toxicity test procedure}

Concentrations of the chemicals for chronic reproduction test were chosen based on 24 and $48 \mathrm{~h}$ preliminary exposure. Acute and chronic tests were conducted according to the OECD standard procedures $(11,12)$. For the acute exposure, four replicates for each treatment and control were used with five neonates for each replicate. There were five concentrations for both tested chemicals. Animals were kept under the same laboratory conditions as those in the chronic test but were not fed. Acute exposure to $\mathrm{CaCl}_{2}$ showed $100 \%$ mobility after $48 \mathrm{~h}$ in 240 and $481 \mathrm{mg} \mathrm{L}^{-1}$ and $60 \%$ mobility in $1925 \mathrm{mg} \mathrm{L}^{-1}$ and for $\mathrm{CaBr}_{2} 90$ and $80 \%$ mobility for 533 and $1066 \mathrm{mg} \mathrm{L}^{-1}$ respectively, so the chronic reproduction test was set with the same chemical concentrations.

For the chronic experiments, neonates from $3^{\text {rd }}-5^{\text {th }}$ brood $\leq 24 \mathrm{~h}$ old (from mothers previously acclimated in dilution water) were placed individually in $50 \mathrm{~mL}$ of test solution in glass beakers covered with watch glass. Ten replicates per test solution and ten replicates as a control were kept at room temperature $\left(20 \pm 2{ }^{\circ} \mathrm{C}\right)$, at $12: 12$ photoperiod. Animals were fed daily with $4 \times 10^{5}$ cell $\mathrm{mL}^{-1}$ of the algae species Chlorella vulgaris and Scenedesmus obliquus 2:1. Three times a week. the animals were transferred to a fresh test solution and test beakers were positioned in a random manner within the testing area, neonates and aborted eggs were recorded and discarded, survival was recorded daily. Dilution water used for preparing test solutions and the controls (ISO test water) contained $11.76 \mathrm{~g} \mathrm{CaCl}_{2} \times 2 \mathrm{H}_{2} \mathrm{O}$, $4.93 \mathrm{~g} \mathrm{MgSO}_{4} \mathrm{x} 7 \mathrm{H}_{2} \mathrm{O}, 2.59 \mathrm{~g} \mathrm{NaHCO}_{3}$, and $0.23 \mathrm{~g} \mathrm{KCl}$.
Each salt was diluted in deionised water to $1 \mathrm{~L}$ and $25 \mathrm{~mL}$ of each solution was added to prepare $1 \mathrm{~L}$ of dilution water. The dilution water had a conductivity of $<10 \mu \mathrm{S} \mathrm{cm}^{-1}, \mathrm{pH}$ 7.8 and hardness $250 \mathrm{mg} \mathrm{L}^{-1} \mathrm{CaCO}_{3}$ (11). ISO test water contains $294 \mathrm{mg} \mathrm{L}^{-1} \mathrm{CaCl}_{2}$ so each exposure $\mathrm{CaCl}_{2}$ concentration was an addition to that content. All chemicals used in the experiments were produced by Merck (Darmstadt, Germany) and of p.a. grade, except $\mathrm{CaBr}_{2}$ which was extra pure grade. The actual concentrations of the chemicals in the test solutions were measured once a week after preparing fresh solutions and they varied from the nominal concentrations \pm 0.1 to $5 \%$. Calcium was measured with a Varian Techron AA5 atomic absorption spectrophotometer (13), bromide was measured by the spectrophotometric method (14), and chloride was measured by silver nitrate volumetric method (15).

\section{Statistical analysis}

The experiments were statistically analysed with onefactorial ANOVA and Tukey post hoc test to reveal the statistical differences between treatments (16), using Statistica 6 (StatSoft, Tulsa, AZ, USA). The half maximal effective concentration $\mathrm{EC}_{50}$ values were calculated using regression analysis and Bonferroni test and the significance of females' mortality was determined using CochranArmitage trend test (12).

\section{RESULTS}

The results are given in Table 1 and Figures 1 and 2 . Our results of the acute immobilisation tests showed that the $\mathrm{EC}_{50} 48$-hour value for $\mathrm{CaCl}_{2}$ was $2020 \mathrm{mg} \mathrm{L}^{-1}(p=0.01)$ and for $\mathrm{CaBr}_{2} 2238.6 \mathrm{mg} \mathrm{L}^{-1}(p=0.003)$.

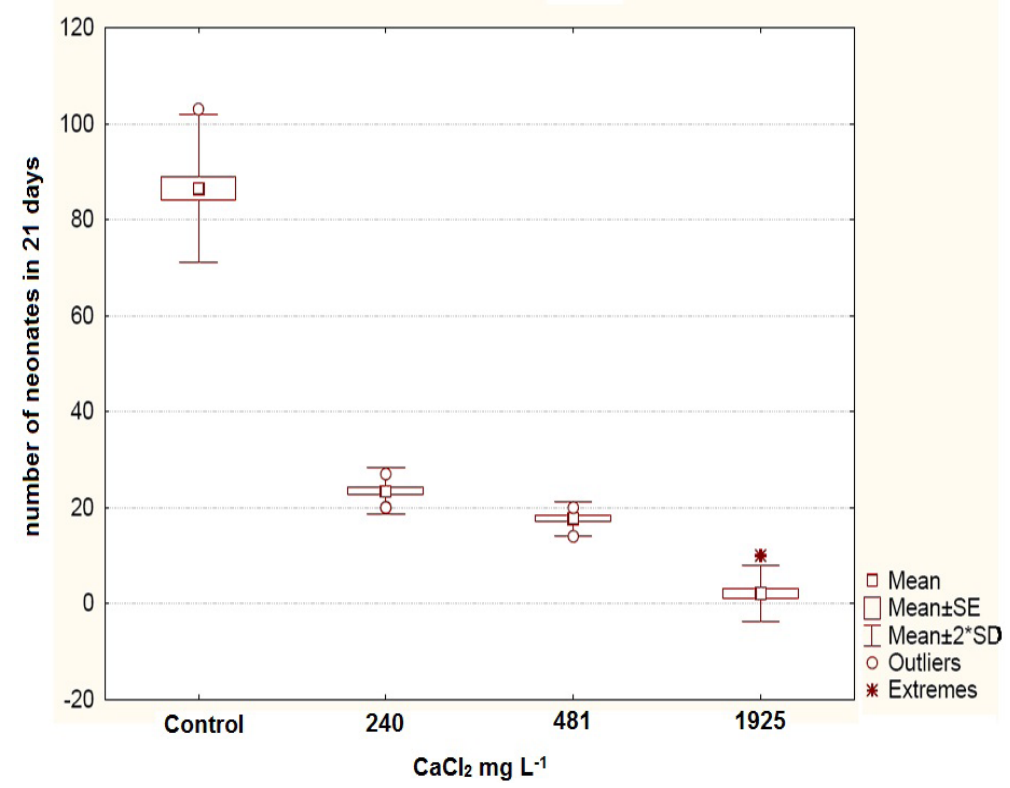

Figure 1 Effect of $\mathrm{CaCl}$, on reproduction of Daphnia magna: mean number of living neonates per female (number of female at the start of the test which did not inadvertently or accidentally die during the test, determined by Cochran-Armitage trend test) 
Table 1 Reproduction and survival of Daphnia magna exposed to $\mathrm{CaCl}_{2}$ and $\mathrm{CaBr}_{2}$ for 21 days

\begin{tabular}{|c|c|c|c|c|c|c|c|c|}
\hline Group & $\begin{array}{c}\text { No. of } \\
\text { neonates }\end{array}$ & $\begin{array}{l}\text { No. of } \\
\text { broods }\end{array}$ & $\begin{array}{c}\text { Brood } \\
\text { size }\end{array}$ & $\begin{array}{l}\text { Days to } 1^{\text {st }} \\
\text { brood }\end{array}$ & $\begin{array}{c}\text { Viable } \\
\text { neonates/ } \\
\text { surviving } \\
\text { female/day }\end{array}$ & $\begin{array}{l}\text { No. of } \\
\text { aborted } \\
\text { eggs }\end{array}$ & $\begin{array}{c}\text { Females' } \\
\text { mortality } \\
\text { (n) }\end{array}$ & $\begin{array}{c}\text { Longevity } \\
\text { (Days) }\end{array}$ \\
\hline Control & $85.5 \pm 7.72$ & $4.5 \pm 0.4$ & $20.7 \pm 3.31$ & $9.7 \pm 0.34$ & $4.1 \pm 0.34$ & 0 & 1 & $20.9 \pm 032$ \\
\hline $\begin{array}{l}\mathrm{CaCl}_{2} \\
240 \mathrm{mg} \mathrm{L}^{-1}\end{array}$ & $23.4 \pm 2.41^{*}$ & $4.1 \pm 0.3$ & $5.7 \pm 0.53^{*}$ & $9.8 \pm 1.03$ & $1.1 \pm 0.12^{*}$ & 0 & 2 & $20.8 \pm 0.42$ \\
\hline $\begin{array}{l}\mathrm{CaCl}_{2} \\
481 \mathrm{mg} \mathrm{L}^{-1}\end{array}$ & $17.7 \pm 1.77^{*}$ & $4.3 \pm 0.4$ & $4.8 \pm 0.81^{*}$ & $10.2 \pm 0.79$ & $0.8 \pm 0.08^{*}$ & 0 & 3 & $20.6 \pm 0.70$ \\
\hline $\begin{array}{l}\mathrm{CaCl}_{2} \\
1925 \mathrm{mg} \mathrm{L}^{-1}\end{array}$ & $2.1 \pm 3.00^{* \#}$ & $0.9 \pm 0.7^{* \#}$ & $1.6 \pm 3.02^{* \#}$ & $11.0 \pm 1.15$ & $0.26 \pm 0.14^{* \#}$ & 0 & 8 & $16.5 \pm 3.84$ \\
\hline $\begin{array}{l}\mathrm{CaBr}_{2} \\
533 \mathrm{mg} \mathrm{L}^{-1}\end{array}$ & - & $3.5 \pm 1.74$ & $5.4 \pm 2.54^{*}$ & $10.2 \pm 0.53$ & - & $21.9 \pm 14.2$ & 6 & - \\
\hline $\begin{array}{l}\mathrm{CaBr}_{2} \\
1066 \mathrm{mg} \mathrm{L}^{-1}\end{array}$ & - & $2.7 \pm 1.62$ & $3.2 \pm 1.80^{*}$ & $12.5 \pm 5.41^{* \$}$ & - & $10.9 \pm 7.22$ & 5 & - \\
\hline
\end{tabular}

The number of females for each group was 10

Results are expressed as mean $\pm \mathrm{SD}$

$S D=$ standard deviation

"Significant difference between groups and the control $(\mathrm{p}<0.001)$

"Significant difference compared to other groups $(\mathrm{p}<0.001)$

${ }^{\$}$ Significant difference compared to other groups $(\mathrm{p}<0.01)$

Statistical differences between groups were determined using one-factorial ANOVA and Tukey post hoc test

The results of chronic reproduction tests showed a significant dose-related reduction of neonate production in all test solutions with $\mathrm{CaCl}_{2}$ compared to the control $(p<0.001)$. At 240 and $481 \mathrm{mg} \mathrm{L}^{-1} \mathrm{CaCl}_{2}$, the neonate production was significantly higher than at $1925 \mathrm{mg} \mathrm{L}^{-1}$ $(p<0.001)$ and mortality was lower by 20 and $30 \%$, respectively. The greatest reduction appeared with the highest concentration of $1925 \mathrm{mg} \mathrm{L}^{-1} \mathrm{CaCl}_{2}$ which caused $80 \%$ mortality (Figure 1, Table 1). Parental mortality in exposed replicates followed a concentration-response pattern as determined by Cochran-Armitage trend test. The $\mathrm{EC}_{50}$ value for reproduction was $900 \mathrm{mg} \mathrm{L}^{-1}$.
Both concentrations of $\mathrm{CaBr}_{2}$ were highly toxic to adults (50 and $60 \%$ mortality) and embryos (100\%) so only aborted eggs were found. There were twice as many produced eggs in the lower concentration of $\mathrm{CaBr}_{2}$ than in the higher concentration (Figure 2, Table 1).

As shown in Table 1, the first-brood day was significantly delayed only in $1066 \mathrm{mg} \mathrm{L}^{-1} \mathrm{CaBr}_{2}$. The average number of neonates per brood decreased in all three $\mathrm{CaCl}_{2}$ concentrations and the average number of broods significantly decreased only in the most toxic solution of $\mathrm{CaCl}_{2}, 1925 \mathrm{mg} \mathrm{L}^{-1}$ (Table 1).

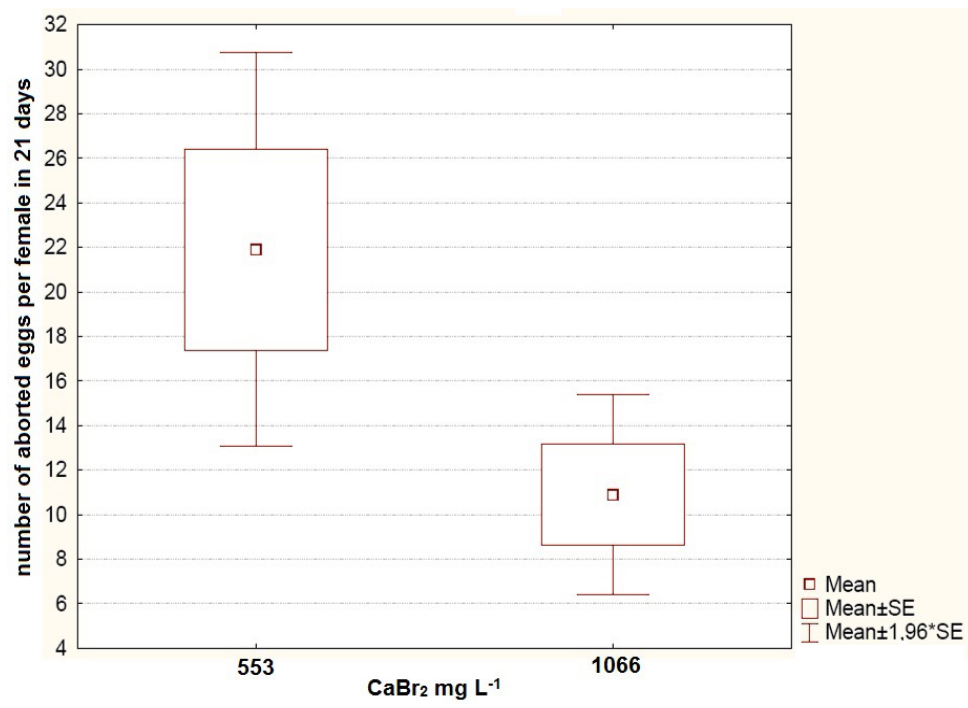

Figure 2 Effect of $\mathrm{CaBr}_{2}$ on reproduction of Daphnia magna: mean number of aborted eggs per female 


\section{DISCUSSION}

A research study on the toxicity of $\mathrm{CaCl}_{2}$ reported that the $\mathrm{EC}_{50}-48 \mathrm{~h}$ for Daphnia magna was $2190 \mathrm{mg} \mathrm{L}^{-1}$ (17). The $\mathrm{EC}_{50}-48 \mathrm{~h}$ value of $2020 \mathrm{mg} \mathrm{L}^{-1}$ determined in this study is very similar to the reported value for the acute toxicity of $\mathrm{CaCl}_{2}$. The results of the reproduction test on daphnids in sublethal concentrations of $\mathrm{CaCl}_{2}$ from the same study (17) showed a significantly lower reproduction compared to the control at the concentration of $1173 \mathrm{mg} \mathrm{L}^{-1}$, but not at lower concentrations ( 235 and $496 \mathrm{mg} \mathrm{L}^{-1}$ ). The highest $\mathrm{CaCl}_{2}$ concentration investigated in our present study (1925 $\mathrm{mg} \mathrm{L}^{-1} \mathrm{CaCl}_{2}$, corresponding to $1230 \mathrm{mg} \mathrm{L}^{-1}$ $\mathrm{Cl}^{-}$) caused $80 \%$ mortality and a significant loss of reproduction in the 21-day reproduction test. The two lower concentrations ( 240 and $481 \mathrm{mg} \mathrm{L}^{-1}$ ) were also significantly toxic so the calculated $\mathrm{EC}_{50}$ amounted to $900 \mathrm{mg} \mathrm{L}^{-1}$. The difference between the reported results and ours could be attributed to the different sensitivity between the D. magna clones or culture conditions $(18,19)$.

A report on the toxicity of chloride to high sensitive cladocerans (20) stated that the chronic toxicity threshold value for reproduction inhibition is $421 \mathrm{mg} \mathrm{L}^{-1} \mathrm{Cl}^{-}$(Daphnia magna 21-day $\mathrm{IC}_{25}$ ) and $454 \mathrm{mg} \mathrm{L}^{-1} \mathrm{Cl}^{-}$(Ceratodaphnia dubia 7-day $\mathrm{IC}_{25}$ ); toxicity tests measuring chloride toxicity were based on using $\mathrm{NaCl}$ to minimize the toxicity contributed by the more toxic counter cation such as $\mathrm{K}^{+}$, $\mathrm{Mg}^{2+}, \mathrm{Ca}^{2+}$. The lowest concentration investigated here (240 $\mathrm{mg} \mathrm{L}^{-1} \mathrm{CaCl}_{2}$, corresponding to $153.3 \mathrm{mg} \mathrm{L}^{-1} \mathrm{Cl}^{-}$) that reduced neonate production to $27 \%$ of the control indicated that $\mathrm{CaCl}_{2}$ could be more toxic than $\mathrm{NaCl}$.

There is a lack of information on the chronic toxicity of $\mathrm{CaBr}_{2}$ to Daphnia magna but data on chronic and acute toxicity of $\mathrm{NaBr}$ are widely distributed in the literature. The NOEC (No Observed Effect Concentration) on fecundity generally ranges from $<3$ to $>117 \mathrm{mg} \mathrm{L}^{-1} \mathrm{NaBr}$ (19). The differences in results may depend on the clone chosen to run the test and laboratory environment $(18,19,21)$. Some of the reported acute toxic values are: $\mathrm{LC}_{50}$ of 7900 and $\mathrm{EC}_{50}$ for reproduction of $29 \mathrm{mg} \mathrm{L}^{-1} \mathrm{NaBr}(22), \mathrm{EC}_{50}$ of 5700 to $10800 \mathrm{mg} \mathrm{L}^{-1} \mathrm{NaBr}(23), \mathrm{EC}_{50} 24 \mathrm{~h}$ of $37.37 \mathrm{mmol} \mathrm{L}^{-1}$ $\mathrm{NaBr}$ (24), etc. Hermens et al. (25) reported an $\mathrm{LC}_{50} 48 \mathrm{~h}$ of 13500 and an $\mathrm{EC}_{50}$ (16-day reproduction) of $29 \mathrm{mg} \mathrm{L}^{-1}$ $\mathrm{NaBr}$ and concluded that the effect on reproduction for compounds like $\mathrm{NaBr}$ is at much lower levels than for acute mortality. Sloof and Canton (26) reported that $\mathrm{NaBr}$ strongly affected daphnid reproduction in a semi-chronic test. Their NOLC (No Observed Lethal Concentration) was $3200 \mathrm{mg} \mathrm{L}^{-1}$ and NOEC (reproduction) $10 \mathrm{mg} \mathrm{L}^{-1} \mathrm{NaBr}$. Based on the results of the long term toxicity tests on $\mathrm{NaBr}$, Canton et al. (27) found that bromide had a marked effect on the reproduction of fresh water organisms (D. magna, Poecilia reticulata, and Lymnaea sp., NOEC was $7.8 \mathrm{mg} \mathrm{L}^{-1}$ $\mathrm{Br}$ ) - the bromide ion was proven to have an embryotoxic effect. Investigating chronic bromide stress on D. magna reproduction in chronic toxicity experiments, Leeuwen et al. (28) found that bromide did not delay the onset of reproduction nor the brood frequency, but disturbed embryonic development so that at $100 \mathrm{mg} \mathrm{L}^{-1} \mathrm{NaBr}$ reproduction was completely inhibited and only aborted eggs were found, but survival was unaffected at up to $10000 \mathrm{mg} \mathrm{L}^{-1}$. Therefore, the authors concluded that bromide inhibited the reproduction process.

The results of the present study on $\mathrm{CaBr}_{2}$ are in good agreement with the former as there were only aborted eggs released by females, significant delay to the onset of reproduction was observed only at $1066 \mathrm{mg} \mathrm{L}^{-1} \mathrm{CaBr}_{2}$ but not at $533 \mathrm{mg} \mathrm{L}^{-1}$. The mean brood frequency in $\mathrm{CaBr}_{2}$ was lowered to 3.5 and 2.7 due to the high mortality of the females before the end of the test. Our results indicate that $\mathrm{CaBr}$, could be more toxic than $\mathrm{NaBr}$, as it caused 50 and $60 \%$ mortality at much lower concentrations than reported for $\mathrm{NaBr}(26,28)$; however, these differences could also be explained with clonal and culturing differences $(18,19,21)$. Many toxicants can cause partial or complete abortion of clutches of eggs and embryo abnormalities e.g. $\mathrm{NaBr}$ and 3,4-dichloroaniline (29), ibuprofen (30), and insecticides (31). An increased number of aborted eggs and a reduction in the number of hatched individuals have been documented in $\mathrm{NaCl}$ solutions at concentrations of $\mathrm{Na}$ ranging from 25 to $249 \mathrm{mg} \mathrm{L}^{-1} \mathrm{Na}^{+}$and 41 to $249 \mathrm{mg} \mathrm{L}^{-1} \mathrm{Na}^{+}$, respectively, in chronic exposure of the freshwater cladoceran Pseudosida ramosa $(32,33)$. Baird et al. (29) reported that the chronic inhibition of reproduction in D. magna at 3 to $17 \mathrm{mg} \mathrm{L}^{-1}$ $\mathrm{NaBr}$ was due solely to the acute lethal effect on eggs developing in the brood chamber. The decreased number of aborted eggs in higher concentration of $\mathrm{CaBr}_{2}$ compared to the lower one in the present study could indicate that such a high concentration of bromide $\left(1066 \mathrm{mg} \mathrm{L}^{-1} \mathrm{CaBr}_{2}\right.$, $852 \mathrm{mg} \mathrm{L}^{-1} \mathrm{Br}$ ) could also affect the production of eggs in the ovarium and not only development in the brood chamber.

Comparing the results of this investigation with those from our previous study on the freshwater snail Planorbarius corneus, it can be concluded that Daphnia magna is more sensitive to the toxic effect of the chemicals than Planorbarius corneus.

The results of this study have also shown that high concentrations of $\mathrm{CaCl}_{2}$ are toxic to Daphnia magna reproduction, reducing offspring production. $\mathrm{CaBr}_{2}$ showed an embryotoxic effect preventing neonate production. The contamination of freshwater with the investigated chemicals near drilling sites could have a harmful effect on Daphnia magna reproduction and reduce the population by reducing its abundance.

Taken together and generally speaking, we can conclude that our findings suggest the need for a more detailed clarification of the toxicity profiles of $\mathrm{CaCl}_{2}$ and $\mathrm{CaBr}_{2}$, primarily because they have demonstrated significant negative impacts on daphnid reproduction. Future studies should focus on examining the effects of these two compounds on other freshwater species. 


\section{REFERENCES}

1. Schmidt DD, Hudson TE, Harris TM. Introduction on brine completion and workover fuids. Part 1 - Chemical and physical properties of clear completion brines. Petrol Eng Int 1983:80-96.

2. Meyer RL, Vargas RH. Process of selecting completion of workover fluids requires series of tradeoffs. Oil Gas J 1984;82:144-8.

3. Hemeida AM, Gawish A. Evaluation the potassium bromide and zinc bromide brines for workover operations. Oil Gas Business 2008;1:1-10

4. Tkalec M, Vidaković-Cifrek Ž, Regula I. The effect of oil industry "High density brines" on duckweed Lemna minor L. Chemosphere 1998;37:2703-15. doi: 10.1016/S00456535(98)00156-8

5. Vidaković-Cifrek Ž, Tkalec M, Horvatić J, Regula I. Effects of oil industry high density brines in miniaturized algal growth bioassay and Lemna Test. Phyton; Special issue: "Plant Physiology" 1999;39:193-7.

6. Vidaković-Cifrek Ž, Wonisch A, Tausz M, Grill D. Effects of $\mathrm{CaCl}_{2}$ and $\mathrm{CaBr}_{2}$ on growth, photosynthetic pigments and ion accumulation in duckweed. Phyton (Austria) 2005;45:183-96.

7. Vujević M, Vidaković-Cifrek Ž, Tkalec M, Tomić M, Regula I. Calcium chloride and calcium bromide aqueous solutions of technical and analytical grade in Lemna bioassay. Chemosphere 2000;41:1535-42. doi: 10.1016/S00456535(00)00070-9

8. Mažuran N, Hršak V, Tomić M, Papeš D. Effects of $\mathrm{CaCl}$ and $\mathrm{CaBr}_{2}$ on the fecundity of Planorbarius corneus L. Chemosphere 1999;38:2345-55.

9. Oda S, Tatarazako N, Watanabe H, Morita M, Iguchi T. Production of male neonates in Daphnia magna (Cladocera, Crustacea) exposed to juvenile hormones and their analogs. Chemosphere 2005;61:1168-74. doi: $10.1016 / j$. chemosphere.2005.02.075

10. Shaw JR, Pfrender ME, Eads BD, Klaper R, Callaghan A, Sibly RM, Colson I, Jansen B, Gilbert, D, Colbourne JK Daphnia as an emerging model for toxicological genomics. Adv Exp Biol 2008;2:165-219. doi: 10.1016/s18722423(08)00005-7

11. Organization of Economic Co-operation and Development (OECD). Guide- lines for the testing of chemicals no. 202. Daphnia sp., acute immobilisation test. Paris: OECD; 2004.

12. Organization of Economic Co-operation and Development (OECD). Guidelines for the testing of chemicals no. 211 Daphnia magna reproduction test. Paris: OECD; 2012.

13. ASTM D 511-93, 1995. Standard test methods for calcium and magnesium in water, Test method B, Atomic Absorption spectrophotometric. Annal Book of ASTM standards, Section 11, Water and Environmental Technology, Vol 11.01 Water (1). Philadelphia (PA): American Society for Testing and Materials; 1995

14. Collins AG, Watkins JW. Spectrophotometric determination of iodides and bromides in oil field brines. Anal Chem 1959;31:1182-4. doi: 10.1021/ac60151a032

15. ASTM D 512-89, 1995. Standard test methods for chloride ion in water. Test method B, Silver nitrate titration. Annual Book of ASTM standards, Section II, Water and Environmental Technology, Vol. 11.01 Water(1). Philadelphia (PA): American Society for Testing and Materials; 1995.

16. Conover WJ. Practical Nonoparametric Statistics. $2^{\text {nd }}$ ed. New York (NY): John Wiley; 1980.

17. Bervoets L, Baillieul M, Blust R, Verheyen R. Evaluation of effluent toxicity and ambient toxicity in a polluted lowland river. Environ Pollut 1996;91:333-41. doi: 10.1016/02697491(96)80915-8

18. Baird DJ, Barber I, Bradley M, Soares AMVM, Calow P. A comparative study of genotype sensitivity to acute toxic stress using clones of Daphnia magna Straus. Ecotoxicol Environ Saf 1991;21:257-65. PMID: 1868782

19. Baird DJ, Barber I, Bradley M, Calow P, Soares AMVM. The Daphnia bioassay: a critique. Hydrobiologia 1989;188/189:403-6. doi: 10.1007/BF00027806

20. Elphick JRF, Bergh KD, Bailey HC. Chronic toxicity of chloride to freshwater species: effects of hardness and implications for water quality guidelines. Environ Toxicol Chem 2011;30:239-46. doi: 10.1002/etc.365

21. Haap T, Köhler HR. Cadmium tolerance in seven Daphnia magna clones is associated with reduced hsp70 baseline levels and induction. Aquat Toxicol 2009;94:131-7. doi: 10.1016/j.aquatox.2009.06.006

22. Canton JH, Sloof W. A Proposal to classify compounds and to establish water quality criteria based on laboratory data. Ecotoxicol Environ Saf 1979;3:126-32. PMID: 540555

23. Naylor C, Cox EJ, Bradley MC, Calow P. Effect of differing maternal food ration on susceptibility of Daphnia magna Straus neonates to toxic substances. Aquat Toxicol 1992;24:75-82. doi: 10.1016/0166-445X(92)90017-H

24. Lilius H, Isomaa B, Holmström T. A comparison of the toxicity of 50 reference chemicals to freshly isolated rainbow trout hepatocytes and Daphnia magna. Aquat Toxicol 1994;30:47-60. doi: 10.1016/0166-445X(94)90005-1

25. Hermens J, Canton H, Steyger N, Wegman R. Joint effects of a mixture of 14 chemicals on mortality and inhibition of reproduction of Daphnia magna. Aquat Toxicol 1984;5:31522. doi: 10.1016/0166-445X(84)90012-2

26. Sloof W, Canton JH. Comparison of the susceptibility of 11 freshwater species to 8 chemical compounds. II. (semi) chronic toxicity tests. Aquat Toxicol 1983;4:271-82.

27. Canton JH, Wester PW, Mathijssen-Spiekman EAM. Study on the toxicity of sodium bromide to different freshwater organisms. Food Chem Toxicol 1983;21:369-78. PMID: 6684619

28. van Leeuwen CJ, Rijkeboer M, Niebeek G .Population dynamics of Daphnia magna as modified by chronic bromide stress. Hydrobiologia 1986;133:277-85. doi: 10.1007/ BF00005599

29. Baird DJ, Barber I, Bradley M, Soares AMVM, Calow P. An early life-stage test with Daphnia magna Straus: an alternative to the 21-day chronic test? Ecotoxicol Environ Saf 1991;22:1-7. PMID: 1914991

30. Heckman LH, Callaghan A, Hooper HL, Connon R, Hutchinson TH, Maund SJ, Sibly RM. Chronic toxicity of ibuprofen to Daphnia magna: Effects on life history traits and population dynamics. Toxicol Lett 2007;172:137-45. doi: 10.1016/j.toxlet.2007.06.001

31. Palma P, Palma VL, Fernandes RM, Bohn A, Soares AMVM, Barbosa IR. Embryo-toxic effects of environmental concentrations of chlorpyrifos on the crustacean Daphnia magna. Ecotoxicol Environ Saf 2009;72:1714-8. doi: 10.1016/j.ecoenv.2009.04.026

32. Freitas EC, Rocha O. Acute and chronic effects of sodium and potassium on the tropical freshwater cladoceran Pseudosida ramosa. Ecotoxicology 2011;20:88-96. doi: 10.1007/s10646-010-0559-z

33. Freitas EC, Rocha O. Effects of sodium and potassium on life history parameters of freshwater cladoceran Pseudosida ramosa. J Braz Soc Ecotoxicol 2012;7:85-91. doi: 10.5132/ jbse.2012.02.013 
Učinak $\mathrm{CaCl}_{2}$ i $\mathrm{CaBr}_{2}$ na razmnožavanje vodenbuhe (Daphnia magna Straus)

Koncentrirane otopine soli $\mathrm{CaCl}_{2}$ i $\mathrm{CaBr}_{2}$ gustoće do $2,3 \mathrm{~kg} \mathrm{~L}^{-1}$ redovito se koriste za kontrolu hidrostatskoga tlaka $\mathrm{u}$ bušotinama tijekom posebnih operacija u istraživanju i proizvodnji prirodnoga plina i sirove nafte. Različite koncentracije soli visoke gustoće često su bile ostavljene u isplačnim jamama u blizini područja bušenja te su prelijevajući se ili ocjeđujući u podzemlje zagađivale slatke i podzemne vode. Iako je dosad već provedeno nekoliko istraživanja toksičnoga učinka koncentriranih otopina soli $\mathrm{CaCl}_{2} \mathrm{i} \mathrm{CaBr}_{2}$, u ovom radu istraživan je učinak $\mathrm{CaCl}_{2}$ i $\mathrm{CaBr}_{2}$ na vodenbuhu Daphnia magna $\mathrm{u}$ dvadesetjednodnevnom testu reprodukcije. Tri ispitane koncentracije $\mathrm{CaCl}_{2}\left(1925,481 \mathrm{i} 240 \mathrm{mg} \mathrm{L}^{-1}\right)$ prouzročile su značajan, o dozi ovisan pad reprodukcije $(p<0,001)$. U otopinama $\mathrm{CaBr}_{2}\left(53311066 \mathrm{mg} \mathrm{L}^{-1}\right)$ proizvedena su samo abortirana jaja, što pokazuje embriotoksičnost te tvari. Rezultati upućuju na to da su visoke koncentracije ispitivanih tvari štetne za razmnožavanje vodenbuhe te mogu smanjiti brojnost tih organizama.

KLJUČNE RIJEČI: akutni test imobilizacije; embriotoksičnost bromida; kronični test reprodukcije; soli visoke gustoće 